\title{
Drying and cooking effects on the final quality of pea grains (Pisum sativum L.) varieties
}

\author{
Dario Camilo PANTOJA ESPINOSAㄹ Jader RODRÍGUEZ CORTINA (D), María HERNÁNDEZ CARRIÓN³, \\ Oswaldo OSORIO MORA ${ }^{4}$
}

\begin{abstract}
Genetic and process factors influence the final quality of dried pea seeds (Pisum sativum L.), particularly the physical properties and the proximal composition. The aim of this work was to evaluate the effect of air-drying temperature $\left(45,50,55\right.$ and $\left.60{ }^{\circ} \mathrm{C}\right)$ and cooking on physical and the proximal composition in two pea varieties ("Obonuco Andina" and "Sureña"). The physical properties and the proximal composition were determined for the best drying treatment. All pea samples were dried until a final moisture content $\leq 15 \%$ (w.b) was reached. The results showed that the drying temperature had a statistically significant effect on the final quality of both pea varieties. The treatment at $55^{\circ} \mathrm{C}$ was determined to be the most suitable because it did not present any testa detachment or generate off-flavors.
\end{abstract}

Keywords: physical properties; proximal composition; final quality.

Practical Application: Drying pea grains at $55^{\circ} \mathrm{C}$ resulted in little damage in grain quality being a point of interest for canned uses.

\section{Introduction}

Nutritional compounds are a growing demand from consumers interested in healthy foods of natural origin. Pea (Pisum sativum L.) is a legume that has a considerable content of proteins, sugars, minerals, vitamins and fiber, in addition to its water content. The pea is one of the major vegetables of the temperate and subtropical world. Due to these features, pea is perishable in nature (water activity of 0.98 at $25^{\circ} \mathrm{C}$ ) (Garg et al., 2014). Drying under controlled conditions is therefore an alternative to conservation in order to reduce post-harvest losses, guaranteeing an increase in its value when water content and activity are decreased to appropriate levels of storage (moisture content $\leq 14 \%$ w.b and water activity $\leq 0.6$ ). Dried pea provides advantages in terms of shelf life and palatability as well as low handling, storage, and transportation costs due to the reduction of weight and volume. This kind of product poses a potential use in canned products, soups, purees, and flours, whose production processes are based on dried peas (Pardeshi et al., 2009).

On the other hand, an inappropriate control of the drying temperature could be harmful to food integrity and quality, due to the way in which water is evaporated. For this reason, the temperature of the process must be considered in order to prevent biochemical, chemical and physical deterioration (Zielinska \& Markowski, 2007). Physical properties such as size, weight, sphericity, true and bulk density, porosity, and angle of repose are essential qualities in the process study and equipment design for harvesting, handling, transformation and storage. Similarly, the study of compositional properties is important to understand the impact on processing conditions (Perea-Flores, 2011).

Today, the consumption of dried products involves rehydration and cooking in order to improve the sensory and nutritional quality of vegetables. Thus, cooking time is an indicator of grain quality, which defines the acceptance by the consumer and determines production and marketing feasibility (Kinyanjui et al., 2017). Grain cooking includes starch gelatinization, protein denaturation, polysaccharide solubilization and collapse, and softening of the structural materials in the cotyledon (Hamid et al., 2016).

Currently, there are no report related to pea drying and cooking. For this reason, this study aims to evaluate the effect of drying temperature and the cooking time on two varieties of pea (var. "Obonuco Andina" and var. "Sureña") on proximate composition, and physical characteristics of grains.

\section{Materials and methods}

\subsection{Materials}

Raw material: The pea grain varieties "Obonuco Andina" and "Sureña" were harvested at the LOPE farm, owned by the National Learning Center (Sena, Nariño, Colombia). Peas were graded, selected, and finally subjected to a constant temperature and relative humidity conditions $\left(20^{\circ} \mathrm{C}\right.$ and $60 \% \mathrm{HR}$, respectively) for $12 \mathrm{~h}$. An expanded polystyrene (EPS) chamber with a calcium chloride interior was used for this purpose.

${ }^{1}$ Centro de Investigación La Libertad, Corporación Colombiana de Investigación Agropecuaria - Agrosavia, Villavicencio, Colombia

${ }^{2}$ Centro de Investigación Tibaitatá, Corporación Colombiana de Investigación Agropecuaria - Agrosavia, Bogotá, Colombia

${ }^{3}$ Grupo de Diseño de Productos y Procesos - GDPP, Facultad de Ingeniería, Universidad de los Andes, Bogotá, Colombia

${ }^{4}$ Grupo de Apoyo a la Investigación y Desarrollo Agroalimentario - GAIDA, Facultad de Ingeniería Agroindustrial, Universidad de Nariño, Pasto, Nariño, Colombia

*Corresponding author: jrodriguezc@agrosavia.co 


\subsection{Drying}

The experiments were carried out in an incubator-type drying equipment (IN-601, Lab Incubator, Gemmy Industrial Corp., Taiwan) containing an air fan programmed at $1.5 \mathrm{~m} / \mathrm{s}$ and a digital temperature controller. The equipment was also provided with internal electric resistances and a drying section with four $30 \times 30 \mathrm{~cm}$ trays.

The drying experiments were done in triplicate at temperatures of $45,50,55$ and $60{ }^{\circ} \mathrm{C}$, until the final moisture content was less than $15 \%$ (w.b). The moisture measurement was performed in an Electronic Moisture Analyzer (Version 1.1, Kern DBS, KERN \& Sohn GmbH, Germany). Once the process was completed, the product was packed in polyethylene bags.

\subsection{Appropriate treatment definition and cooking time test}

Cooking test was performed in order to define the process time for each pea variety. The dried grains were first rehydrated in distilled water for $12 \mathrm{~h}$, and then cooked in a pea-boiling water $\left(85^{\circ} \mathrm{C}\right)$ ratio of $1: 10$. The hardness of the grain was evaluated each minute until four favorable quality observations were obtained. The qualities considered were easy chewing, pasty and smooth consistency, as well as a fine to lumpy taste and sense on palate. The quality of the grain, in terms of off flavor generation and testa damage or detachment, was the criterion considered for its final selection (Bilbao-Reboredo et al., 2000; Ghalavand et al., 2011; Rahman, 2007).

\subsection{Physical properties of the grains dried with the appropriate treatment}

Having defined the appropriate treatment, the physical and proximal properties of pea varieties were studied for both fresh and dried states. The physical properties measured were sphericity, arithmetic and geometric diameter. The dimensions of 100 peas were measured, considering their width $(X)$, length (Y) and thickness (Z). A vernier caliper was used for these measurements. The sphericity, arithmetic diameter and geometric diameter were calculated with the Equations 1, 2 and 3 (Obi et al., 2014):

$\phi=\frac{(\mathrm{XYZ})^{1 / 3}}{\mathrm{~L}}$

$\mathrm{Da}=\frac{\mathrm{X}+\mathrm{Y}+\mathrm{X}}{3}$

$\mathbf{D g}=(\mathrm{XYZ})^{1 / 3}$

where $\phi$ is sphericity, $\mathrm{Da}$ is the arithmetic diameter in $\mathrm{cm}$, and $\mathrm{Dg}$ is the geometric diameter in $\mathrm{cm}$.

The weight $(\mathrm{W})$ was determined with an OHAUS Analytical Balance. The weight of 100 peas was used to extrapolate the weight of 1000 grains, recording the results in grams (Unal et al., 2017). The bulk density was determined according to Equation 4 (Singh \& Goswami, 1996).

$\rho b=\frac{\operatorname{Mrl}-\mathrm{Mrv}}{\mathrm{Vr}}$ where $\rho b$ is the bulk density $\left(\mathrm{g} / \mathrm{cm}^{3}\right), \mathrm{Mrl}$ is the mass of the filled beaker $(\mathrm{g})$; Mrv is the mass of the empty container $(\mathrm{g})$; $\mathrm{Vr}$ is the container volume $\left(\mathrm{cm}^{3}\right)$.

The true density was determined with Equation 5 through the pycnometer method. A $50 \mathrm{~mL}$ pycnometer was used, along with $99.8 \%$ ethanol with a density of $0.790 \mathrm{~g} / \mathrm{mL}$ (Yalçın et al., 2007).

$\rho t=\frac{(w p s-w p)}{(w p l-w p)-(w p l s-w p s)} \rho l$

where $\rho t$ is the real density $\left(\mathrm{g} / \mathrm{cm}^{3}\right)$; wps is the mass of pycnometer with the sample $(\mathrm{g})$; wp is the mass of the empty pycnometer ( $\mathrm{g}$ ); wpl is the mass of the pycnometer with ethanol ( $\mathrm{g}$ ); wpls is the mass of the pycnometer with sample and ethanol $(\mathrm{g}) ; \rho \mathrm{l}$ is the ethanol density $(\mathrm{g} / \mathrm{mL})$.

The bulk porosity was calculated using Equation 6, based on the true and bulk densities (Obi et al., 2014).

$\varepsilon=\left(1-\frac{\rho b}{\rho t}\right) * 100$

where $\varepsilon$ is the porosity $(\%) ; \rho b$ is the bulk density $(\mathrm{g} / \mathrm{mL})$; and $\rho t$ is the true density $(\mathrm{g} / \mathrm{mL})$.

The angle of repose was estimated using Equation 7. An empty cylindrical mold (100 $\mathrm{mm}$ diameter x $150 \mathrm{~mm}$ high) was filled with peas on a wooden surface; the container was slowly raised until particles formed a cone (Kalamullah \& Gunasekar, 2002).

$\emptyset=\mathrm{TAN}-1\left(\frac{2 \mathrm{H}}{\mathrm{D}}\right)$

where " $\varnothing$ " is the angle of repose $\left(^{\circ}\right), \mathrm{H}$ is the formed cone height $(\mathrm{cm})$ and $\mathrm{D}$ its diameter $(\mathrm{cm})$.

\subsection{Proximal composition of the grains dried with the appropriate treatment}

The proximal properties of grains were measured at the Specialized Laboratories of the University of Nariño. The protein, nitrogen free extract, ether extract, crude fiber, energy, minerals (calcium, phosphorus, magnesium, potassium, sulfur, iron, manganese, zinc, cooper) and vitamin $\mathrm{C}$ contents were determined using AOAC methods (Cunniff, 1997).

\subsection{Experimental design}

A multilevel factorial design with three replications was conducted. The factors were pea varieties ("Obonuco Andina" and "Sureña") and drying temperatures $\left(45,50,55\right.$ and $\left.60^{\circ} \mathrm{C}\right)$. The response variable represented the drying time required to reach a final moisture $\leq 15 \%$ (w.b). The statistical software Minitab 18 was employed for this purpose.

\section{Results and discussion}

\subsection{Drying}

The initial values of moisture content of the "Obonuco Andina" and "Sureña" varieties were $65.6 \pm 4.0$ and $68.5 \pm 1.0 \%$ (w.b), 
respectively. The initial values of water activity for each variety were $0.97 \pm 0.01$ and $0.97 \pm 0.01$ at room temperature $\left(18^{\circ} \mathrm{C}\right)$.

The drying times for each experiment at $45,50,55$ and $60^{\circ} \mathrm{C}$ and for both pea varieties are described in Table 1. The pea varieties "Obonuco Andina" and "Sureña" showed similar time behaviors at each temperature. Similar results are reported in other studies on pea varieties $\mathrm{Pb}-87, \mathrm{~Pb}-88$ and Matar Ageta-6 (Pardeshi et al., 2009), as well as in varieties of millet (Ojediran, 2010) and yam (Montes et al., 2008).

Results showed that only drying temperature had a statistically significant effect ( $p$-value $<0.05$ ) on time required to reach a final moisture content below $15 \%$ (w.b). The effect of temperature on the decrease in time required to reach a certain moisture value has been reported by several investigations (Chkir et al., 2015; Jabeen et al., 2015).

These results can be demonstrated with the mean plots (Figure 1). Results show that the increase in drying temperature caused a significant decrease $(\mathrm{p}<0.05)$ in the time required to reach a final moisture content below 15\% (w.b). On the other hand, when different pea varieties were used, no significant effect in drying time was observed ( $p>0.05)$.

As it is shown in Table 1, drying at 55 and $60^{\circ} \mathrm{C}$ allowed for a lower drying time. This fact together with the moisture content values obtained that could prevent the legume degradation by microorganisms and enzymes attack, ensuring a shelf life of around one year under dry and dark conditions, limited aeration, and protection against contaminants (Jovanovic, 2013). Furthermore, the water activity values obtained (lower than 0.6, data not shown), that imply a better stability of dried grains, considering interactions between internal water and pea components (Téllez-Pérez et al., 2015).

Table 1. Drying time values.

\begin{tabular}{lcc}
\hline Variety & $\mathrm{T}\left({ }^{\circ} \mathrm{C}\right)$ & Drying time $(\mathrm{min})$ \\
\hline \multirow{4}{*}{ Obonuco Andina } & $\mathbf{4 5}$ & $913.3 \pm 11.5$ \\
& $\mathbf{5 0}$ & $633.3 \pm 41.6$ \\
& $\mathbf{5 5}$ & $540.0 \pm 20.0$ \\
\multirow{4}{*}{ Sureña } & $\mathbf{6 0}$ & $353.3 \pm 11.5$ \\
& $\mathbf{4 5}$ & $913.3 \pm 11.5$ \\
& $\mathbf{5 0}$ & $646.7 \pm 11.5$ \\
& $\mathbf{5 5}$ & $520.0 \pm 0.00$ \\
& $\mathbf{6 0}$ & $366.7 \pm 11.5$ \\
\hline
\end{tabular}

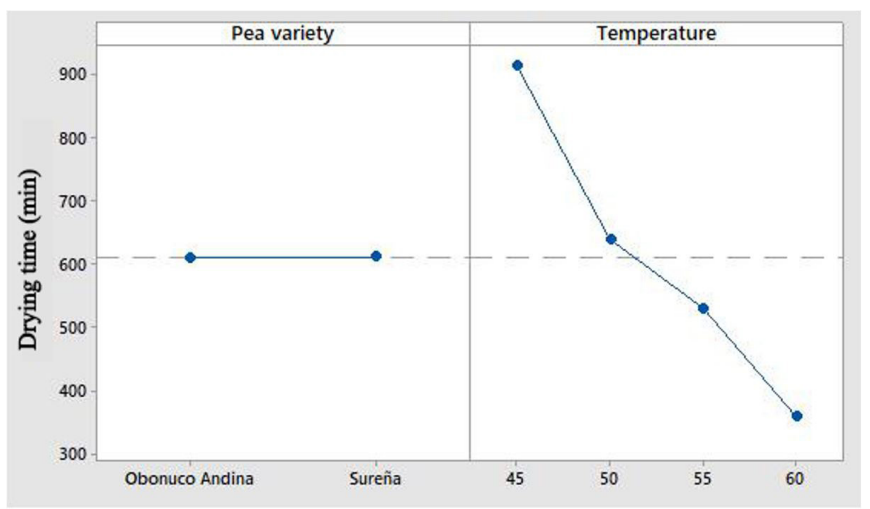

Figure 1. Mean plots for the variable drying time.

\subsection{Determination of the best processing conditions}

A cooking test with both pea varieties was carried out. Both "Obonuco Andina" and "Sureña" varieties treated at $60{ }^{\circ} \mathrm{C}$ obtained shorter cooking times compared to those of peas dried at $55^{\circ} \mathrm{C}$ (Figure 2).

The cooking time was affected by the drying temperature, a result that is similar to those observed in other grains such as kidney bean (Bilbao-Reboredo et al., 2000) and other common bean varieties (Rose coco, Canadian wonder, Pinto and Red haricot) (Kinyanjui et al., 2017). As shown in Figure 2, both varieties showed similar cooking patterns In this investigation, the claims of some authors are refuted as the genetic characteristics of vegetal material did not show any remarkable effect on cooking time, which could be explained by the similar growing conditions (Valladares-Sevilla, 1996).

The degree of water evaporation at 55 and $60^{\circ} \mathrm{C}$ generated a weakening of the cell structure and a collapse of the protein-starch matrix. Both thermal and mechanical stresses were generated by moisture gradients within the grain, decreasing pea resistance, coat permeability, and cotyledon structure (Zielinska et al., 2013). As a result, a faster rehydration and cooking were obtained. Some investigations point out drastic drying temperatures affect cellular integrity in food and therefore it is facilitated the heat and mass transfer (Russo et al., 2013). An inner structural material of the pea, called the "middle lamella", was affected by the drying conditions, generating the disruption and softening phenomena (Kinyanjui et al., 2017).

Cotyledon and testa expansions resulted after rehydration and cooking, which caused coating injuries and testa detachments. The brownish tones were intensified by temperature increases that enhance Maillard and enzymatic reactions, as well as by ascorbic acid and carotenoids breakdown. Pheophytins and pheophorbides were produced from chlorophyll degradation (Ali et al., 2014). Peas dried at $60{ }^{\circ} \mathrm{C}$ had odd flavors due to volatile removal and acetaldehyde and ethyl acetate generation (Rahman, 2007).

Although drying at $60{ }^{\circ} \mathrm{C}$ involved lower cooking times, the damages were more evident (Figure 3B). For this reason, the treatment at $55^{\circ} \mathrm{C}$ was chosen as the appropriate condition for both pea varieties.

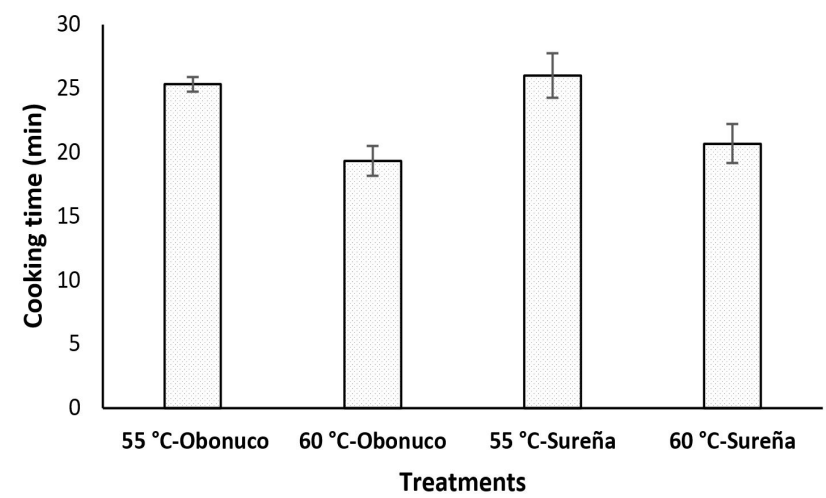

Figure 2. Cooking time samples pea. 

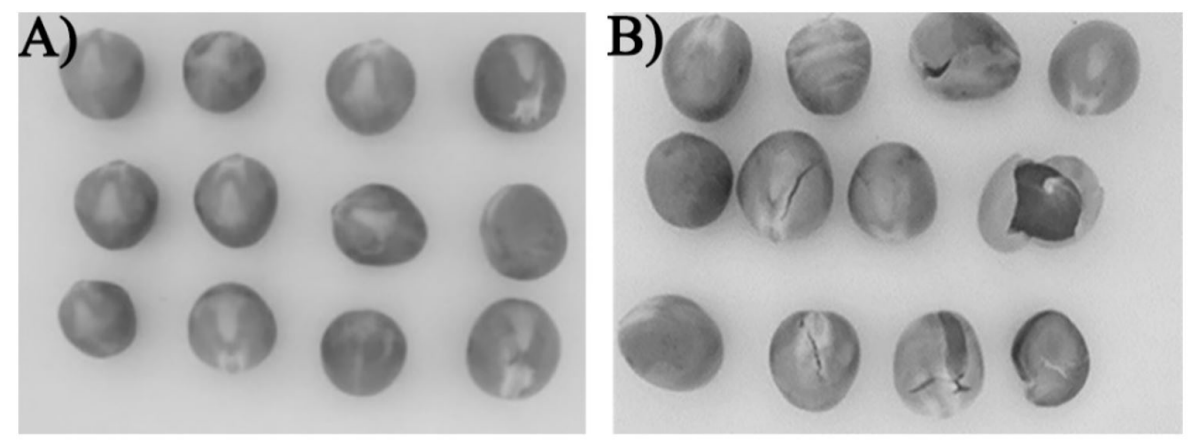

Figure 3. (A) Sureña variety dried at $55^{\circ} \mathrm{C}$ and (B) Sureña variety dried at $60^{\circ} \mathrm{C}$ rehydrated and cooked.

Table 2. Physical properties of pea varieties studied, in fresh and dry state with proper treatment. (mean value \pm standard deviation).

\begin{tabular}{|c|c|c|c|c|}
\hline \multirow{2}{*}{ Parameter } & \multicolumn{2}{|c|}{ Pea variety "Obonuco Andina" } & \multicolumn{2}{|c|}{ Pea Variety "Sureña" } \\
\hline & Untreated & Dried & Untreated & Dried \\
\hline $\mathrm{X}(\mathrm{cm})$ & $1.010 \pm 0.036$ & $0.828 \pm 0.051$ & $1.024 \pm 0.042$ & $0.834 \pm .061$ \\
\hline $\mathrm{Y}(\mathrm{cm})$ & $1.185 \pm 0.051$ & $0.927 \pm 0.055$ & $1.188 \pm 0.052$ & $0.925 \pm 0.085$ \\
\hline $\mathrm{Z}(\mathrm{cm})$ & $0.999 \pm 0.047$ & $0.743 \pm 0.058$ & $1.006 \pm 0.043$ & $0.755 \pm 0.063$ \\
\hline$\phi$ & $1.052 \pm 0.028$ & $1.001 \pm 0.045$ & $1.045 \pm 0.034$ & $1.002 \pm 0.049$ \\
\hline $\mathrm{Da}(\mathrm{cm})$ & $1.065 \pm 0.036$ & $0.833 \pm 0.040$ & $1.073 \pm 0.035$ & $0.838 \pm 0.050$ \\
\hline $\operatorname{Dg}(\mathrm{cm})$ & $1.061 \pm 0.035$ & $0.829 \pm 0.040$ & $1.069 \pm 0.032$ & $0.834 \pm 0.048$ \\
\hline W (g) & $8300 \pm 100$ & $297.431 \pm 5.852$ & $7966.667 \pm 57.735$ & $300.176 \pm 5419$ \\
\hline$\rho b\left(g / \mathrm{cm}^{3}\right)$ & $0.567 \pm 0.006$ & $0.594 \pm 0.005$ & $0.568 \pm 0.003$ & $0.587 \pm 0.002$ \\
\hline$\rho t\left(\mathrm{~g} / \mathrm{cm}^{3}\right)$ & $1.078 \pm 0.010$ & $0.959 \pm 0.027$ & $1.112 \pm 0.033$ & $0.979 \pm 0.030$ \\
\hline$\varepsilon(\%)$ & $47.710 \pm 0.939$ & $38.063 \pm 1.667$ & $48.911 \pm 1.788$ & $39.97 \pm 1.801$ \\
\hline$\varnothing\left({ }^{\circ}\right)$ & $30.673 \pm 2.689$ & $14.056 \pm 0.135$ & $28.283 \pm 2.993$ & $13.648 \pm 0.558$ \\
\hline
\end{tabular}

\subsection{Physical quality of the grains dried with the appropriated treatment}

The results of the physical properties of the pea varieties "Obonuco Andina" and "Sureña" untreated and dried at $55{ }^{\circ} \mathrm{C}$ are presented in Table 2. A cotyledon shrinkage was observed, could be caused as a result of non-uniform absorption of energy in the whole volume, generating a perpendicular fracture in the longitudinal axis (Zielinska et al., 2013).

The axial dimensions of both "Obonuco Andina" and "Sureña" varieties were reduced by the percentages of: $21.79 \%$ and $22.13 \%$ for length; $17.80 \%$ and $18.49 \%$ for width; and $25.66 \%$ and $24.93 \%$ for thickness, respectively. The reduction in size was reflected in the decrease of the arithmetic and geometric diameters, which decreased by $21.75 \%$ and $21.88 \%$ for the "Obonuco Andina" variety, and $21.85 \%$ and $21.99 \%$ for the "Sureña" variety, respectively. The shrinking occurred as a result of water removal and stress in the legume structure during the drying at $55{ }^{\circ} \mathrm{C}$. Furthermore, the weight decreased by $96.42 \%$ and $96.23 \%$ for "Obonuco Andina" and "Sureña" varieties, respectively. Despite the size reduction, dried grains retained their spherical shape, as reported in other investigations (Udomkun et al., 2014).

The replacement of water by air in the inner structure contributed to the reduction of the true density after drying (Table 2), which was reported previously in several studies carried out in peas (Hatamipour \& Mowla, 2003), mung beans (Ampah, 2011) and other grains (Jena \& Sahoo, 2017). On the other hand, the bulk density increased as moisture and size were decreased in both "Obonuco Andina" and "Sureña" varieties, creating a greater packaging capacity. This event allowed for a decrease in the inter-granular volume of air, as reported with sorghum (Mwithiga \& Sifuna, 2006), chickpea (Konak et al., 2002) and caper seeds (Dursun et al., 2007).

The porosity after drying decreased (Table 2), which could be caused because the volume of untreated pea grains the air gaps are greater than those obtained after drying (Zielinska et al., 2013). Similar results were reported in chickpea (Konak et al., 2002), coffee, soybeans, pumpkin seeds and peanuts (Baryeh, 2001).

\subsection{Proximal composition of the grains dried with the appropriate treatment}

A concentration of proximal components in a smaller mass was obtained by comparing the weight of fresh peas with that of dried grains (Table 3). However, a compositional degradation induced by the drying temperature and the process time should be recognized (Agoreyo et al., 2011). Tannin formation due to Maillard reactions and denaturation of proteins could have occurred during the process, which could lead to losses in content, digestibility, and biological value. It is possible that lysine, one of the most important amino acids in pea, also decreased ( $\mathrm{Wu}$ \& Mao, 2008).

The nitrogen-free extract (Table 3) could have increased due to the concentration of starch, sugar, pectin and organic acids, which is demonstrated by the increase in the calorie content of the dried grain (Cerquera-Peña et al., 2013). In addition to 
Table 3. Proximal composition of the grains dried with the appropriate treatment.

\begin{tabular}{|c|c|c|c|c|}
\hline \multirow[t]{2}{*}{ Parameter } & \multicolumn{2}{|c|}{$\begin{array}{c}\text { "Obonuco Andina" } \\
\text { Variety } \\
\end{array}$} & \multicolumn{2}{|c|}{ "Sureña" Variety } \\
\hline & Untreated & Dried & Untreated & Dried \\
\hline Protein & 8.73 & 20.8 & 8.53 & 19.8 \\
\hline $\begin{array}{l}\text { Nitrogen free extract } \\
(\mathrm{g} / 100 \mathrm{~g})\end{array}$ & 26.2 & 59.6 & 24.8 & 61.9 \\
\hline Ether Extract (g/100 g) & 0.62 & 1.1 & 0.6 & 1.25 \\
\hline Fiber $(\mathrm{g} / 100 \mathrm{~g})$ & 2.59 & 6.68 & 2.37 & 6.25 \\
\hline $\operatorname{Ash}(g / 100 \mathrm{~g})$ & 1.19 & 2.37 & 1.15 & 2.47 \\
\hline Energy kcal/100 g & 169 & 393 & 160 & 398 \\
\hline Calcium (g/100 g) & 39.6 & 70.1 & 37.5 & 73.6 \\
\hline Phosphorus (g/100 g) & 150 & 312 & 154 & 357 \\
\hline Magnesium (g/100 g) & 57.5 & 107 & 53.5 & 102 \\
\hline Potassium & 378 & 851 & 399 & 889 \\
\hline Sulfur (g/100 g) & 59.4 & 89.3 & 54.7 & 120 \\
\hline $\operatorname{Iron}(\mathrm{g} / 100 \mathrm{~g})$ & 2.98 & 7.12 & 2.95 & 5.36 \\
\hline Manganese (g/100 g) & 0.38 & 1.43 & 0.39 & 1.51 \\
\hline Zinc $(\mathrm{g} / 100 \mathrm{~g})$ & 1.47 & 3.16 & 1.45 & 3.15 \\
\hline Copper $(g / 100 \mathrm{~g})$ & 0.3 & 0.58 & 0.3 & 0.64 \\
\hline Vitamin C (g/100 g) & 0.07 & 0.03 & 0.06 & 0.03 \\
\hline
\end{tabular}

gelatinization of starch and the conversion of sugars to aldehydes, drying at $55^{\circ} \mathrm{C}$ resulted in the oxidation of the ether extract constituents under the presence of ions. This last phenomenon is related to the formation of peroxides and quality loss of protein and vitamins (Hernández-Londoño et al., 2011).

Pea pectin was eliminated by cell membrane disintegration, decreasing the fiber content. Moreover, ash and minerals were unaffected after treatment at $55^{\circ} \mathrm{C}$ on account of their low volatility (Potter \& Hotchkiss, 1999). Nevertheless, vitamin C content was reduced due to its labile nature; this vitamin was oxidized to dehydroascorbic acid and subsequently to diketogluonic acid (Kiremire et al., 2010). Similar result was reported in red peppers (Di Scala \& Crapiste, 2008).

In this study the best treatment with respect to physical quality parameters was selected. However, previous research has highlighted the importance of sensorial analysis (HernándezCarrión et al., 2015; Quartieri Nascimento et al., 2020) in order to know the customer's perception. So, sensory methods could be performed and considered as decision variable in order to select the best treatment in future studies.

\section{Conclusions}

Pea grains are sensible to drying air temperature. An appropriated treatment could be particularly important to avoid internal seed breakage, cracking, splitting and especially when the proximal components can be retained. The drying process at $55{ }^{\circ} \mathrm{C}$ was defined as the appropriate treatment for both varieties of pea. Likewise, this process resulted in little damage to the cooked grain quality, based on the assessment of testa detachment and generation of off flavors, being a point of interest for canned uses.

\section{Acknowledgements}

The authors would like to acknowledge the University of Nariño for its support, and "Sistema General de Regalías" for the financial contribution to the project BPIN 2012000100188, which financed part of this study. Moreover, the authors wish to thank "Centro de Idiomas" from the Universidad de Nariño for assistance with the English manuscript.

\section{References}

Agoreyo, B., Akpiroroh, O., Orukpe, O., Osaweren, O., \& Owabor, C. (2011). The effects of various drying methods on the nutritional composition of Musa paradisiaca, Dioscorea rotundata and Colocasia esculenta. Asian Journal of Biochemistry, 6(6), 458-464. http://dx.doi. org/10.3923/ajb.2011.458.464.

Ali, M., Yusof, Y., Chin, N., Ibrahim, M., \& Basra, S. (2014). Drying kinetics and colour analysis of Moringa oleifera leaves. Agriculture and Agricultural Science Procedia, 2, 394-400. http://dx.doi.org/10.1016/j. aaspro.2014.11.055.

Ampah, J. (2011). Effect of rewetting and drying on selected physical properties of Asontem cowpea variety (Master's thesis). Kwame Nkrumah University of Science and Technology, Kumasi, Ghana.

Baryeh, E. A. (2001). Physical properties of bambara groundnuts. Journal of Food Engineering, 47(4), 321-326. http://dx.doi.org/10.1016/ S0260-8774(00)00136-9.

Bilbao-Reboredo, T., Hampe-Amador, S., Addae-Smith, R., PuertaGarcía, F., \& Ledesma-Rivero, L. (2000). Ocurrencia de tóxicos naturales en frijol colorado (Phaseolus vulgaris) y arveja (Pisum sativum): efecto del tiempo de almacenamiento y los tratamientos caseros. Revista Facultad Nacional de Agronomía, 53(1), 901-912.

Cerquera-Peña, N. E., Parra-Coronado, A., \& Camacho-Tamayo, J. H. (2013). Determinación de variables de secado en lámina para la deshidratación de pulpa de maracuyá. Revista Colombiana de Ciencias Horticolas, 6(2), 172-182. http://dx.doi.org/10.17584/ rcch.2012v6i2.1975.

Chkir, I., Balti, M. A., Ayed, L., Azzouz, S., Kechaou, N., \& Hamdi, M. (2015). Effects of air drying properties on drying kinetics and stability of cactus/brewer's grains mixture fermented with lactic acid bacteria. Food and Bioproducts Processing, 94, 10-19. http://dx.doi. org/10.1016/j.fbp.2014.12.003.

Cunniff, P. (1997). Official methods of analysis of AOAC International. Maryland: AOAC.

Di Scala, K., \& Crapiste, G. (2008). Drying kinetics and quality changes during drying of red pepper. Lebensmittel-Wissenschaft + Technologie, 41(5), 789-795. http://dx.doi.org/10.1016/j.lwt.2007.06.007.

Dursun, I., Tuğrul, K., \& Dursun, E. (2007). Some physical properties of sugarbeet seed. Journal of Stored Products Research, 43(2), 149155. http://dx.doi.org/10.1016/j.jspr.2006.03.001.

Garg, M., Sharma, S., Varmani, S. G., \& Sadhu, S. D. (2014). Drying kinetics of thin layer pea pods using tray drying. International Journal of Food and Nutritional Sciences, 3(3), 61.

Ghalavand, Y., Hatamipour, M., \& Rahimi, A. (2011). Kinetics study of green peas drying in a spouted bed in the presence of a heat carrier. Drying Technology, 29(14), 1648-1655. http://dx.doi.org/10.1080/0 7373937.2011.595564.

Hamid, S., Muzaffar, S., Wani, I. A., Masoodi, F. A., \& Bhat, M. M. (2016). Physical and cooking characteristics of two cowpea cultivars grown in temperate Indian climate. Journal of the Saudi Society of Agricultural Sciences, 15(2), 127-134. http://dx.doi.org/10.1016/j. jssas.2014.08.002. 
Hatamipour, M., \& Mowla, D. (2003). Correlations for shrinkage, density and diffusivity for drying of maize and green peas in a fluidized bed with energy carrier. Journal of Food Engineering, 59(2-3), 221-227. http://dx.doi.org/10.1016/S0260-8774(02)00461-2.

Hernández-Carrión, M., Varela, P., Hernando, I., Fiszman, S., \& Quiles, A. (2015). Persimmon milkshakes with enhanced functionality: Understanding consumers' perception of the concept and sensory experience of a functional food. Lebensmittel-Wissenschaft + Technologie, 62(1), 384-392. http://dx.doi.org/10.1016/j.lwt.2014.10.063.

Hernández-Londoño, C., Ossa, Z. K., Ramírez, L., \& Herrera-Valencia, W. (2011). Influencia del espesor y la temperatura en el secado de carambola (Averrhoa carambola L.). Ingenierías \& Amazonia, 4(2), 131-142.

Jabeen, R., Aijaz, T., \& Gul, K. (2015). Drying kinetics of potato using a self-designed cabinet dryer. Cogent Food \& Agriculture, 1(1), 1036485. http://dx.doi.org/10.1080/23311932.2015.1036485.

Jena, S., \& Sahoo, A. (2017). Studies on the effects of physical properties of feed samples on the performance of fluidized bed dryer. Particulate Science and Technology, 35(2), 166-172. http://dx.doi.org/10.1080/ 02726351.2016.1143068.

Jovanovic, S. (2013). Quality characterization and modeling experimental kinetics in pilot scale heat pump drying of green peas (Master's thesis). Norwegian University of Science and Technology, Trondheim, Noruega.

Kalamullah, S., \& Gunasekar, J. (2002). Moisture-dependent physical properties of arecanut kernel. Biosystem Engineering Journal, 82(3), 331-338.

Kinyanjui, P. K., Njoroge, D. M., Makokha, A. O., Christiaens, S., Sila, D. N., \& Hendrickx, M. (2017). Quantifying the effects of postharvest storage and soaking pretreatments on the cooking quality of common beans (Phaseolus vulgaris). Journal of Food Processing and Preservation, 41(4), e13036. http://dx.doi.org/10.1111/jfpp.13036.

Kiremire, B., Musinguzi, E., Kikafunda, J., \& Lukwago, F. (2010). Effects of vegetable drying techniques on nutrient content: a case study of south-western Uganda. African Journal of Food, Agriculture, Nutrition and Development, 10(5). http://dx.doi.org/10.4314/ ajfand.v10i5.56341.

Konak, M., Carman, K., \& Aydin, C. (2002). PH—postharvest technology: physical properties of chick pea seeds. Biosystems Engineering, 82(1), 73-78. http://dx.doi.org/10.1006/bioe.2002.0053.

Montes, E. J. M., Gallo, R. T., Pizarro, R. D. A., Sierra, O. A. P., Escobar, J. L. M., \& Herazo, I. I. M. (2008). Modelado de la cinética de secado de ñame (dioscorea rotundata) en capa delgada. Ingenieria e Investigacion, 28(2), 45-52.

Mwithiga, G., \& Sifuna, M. M. (2006). Effect of moisture content on the physical properties of three varieties of sorghum seeds. Journal of Food Engineering, 75(4), 480-486. http://dx.doi.org/10.1016/j. jfoodeng.2005.04.053.

Obi, O., Anyadike, C., \& Onyeke, C. (2014). Moisture-dependent physical properties of pigeon pea grown in Nigeria. World Applied Sciences Journal, 31(8), 1396-1405.

Ojediran, J. (2010). Thin layer drying of millet and effect of temperature on drying characteristics. International Food Research Journal, 17, 1095-1106.
Pardeshi, I., Arora, S., \& Borker, P. (2009). Thin-layer drying of green peas and selection of a suitable thin-layer drying model. Drying Technology, 27(2), 288-295. http://dx.doi.org/10.1080/07373930802606451.

Perea-Flores, M. J. (2011). Efecto del secado por lecho fluidizado en la estructura de semillas de Ricinus communis y en la extracción de su aceite como fuente alternativa de biocombustibles ( $\mathrm{PhD}$ thesis). Instituto Politécnico Nacional, México D.F.

Potter, N. N., \& Hotchkiss, J. H. (1999). Ciencia de los alimentos. Zaragoza: Acribia.

Quartieri Nascimento, R., Guimarães Tavares, P. P. L., Meireles, S., Araújo dos Anjos, E., Barreto de Andrade, R., Souza Machado, B. A., Costa Souza, A. L., \& Oliveira Mamede, M. E. (2020). Study on the sensory acceptance and check all that apply of mixed juices in distinct Brazilian regions. Food Science and Technology, 39, 152-158.

Rahman, M. S. (2007). Handbook of food preservation. Boca Raton: CRC Press. http://dx.doi.org/10.1201/9781420017373.

Russo, P., Adiletta, G., \& Di Matteo, M. (2013). The influence of drying air temperature on the physical properties of dried and rehydrated eggplant. Food and Bioproducts Processing, 91(3), 249-256. http:// dx.doi.org/10.1016/j.fbp.2012.10.005.

Singh, K., \& Goswami, T. (1996). Physical properties of cumin seed. Journal of Agricultural Engineering Research, 64(2), 93-98. http:// dx.doi.org/10.1006/jaer.1996.0049.

Téllez-Pérez, C., Sobolik, V., Montejano-Gaitán, J. G., Abdulla, G., \& Allaf, K. (2015). Impact of swell-drying process on water activity and drying kinetics of Moroccan pepper (Capsicum annum). Drying Technology, 33(2), 131-142. http://dx.doi.org/10.1080/07373937.2014.936556.

Udomkun, P., Nagle, M., Mahayothee, B., \& Müller, J. (2014). Laserbased imaging system for non-invasive monitoring of quality changes of papaya during drying. Food Control, 42, 225-233. http://dx.doi. org/10.1016/j.foodcont.2014.02.010.

Unal, H., Izli, G., Izli, N., \& Asik, B. B. (2017). Comparison of some physical and chemical characteristics of buckwheat (Fagopyrum esculentum Moench) grains. CYTA: Journal of Food, 15(2), 257-265. http://dx.doi.org/10.1080/19476337.2016.1245678.

Valladares-Sevilla, B. C. (1996). Determinación del tiempo de cocción en variedades comerciales de frijol rojo (Bs thesis). Universidad Zamorano, Zamorano, Honduras.

$\mathrm{Wu}, \mathrm{T}$, \& Mao, L. (2008). Influences of hot air drying and microwave drying on nutritional and odorous properties of grass carp (Ctenopharyngodon idellus) fillets. Food Chemistry, 110(3), 647-653. http://dx.doi.org/10.1016/j.foodchem.2008.02.058.

Yalçın, İ., Özarslan, C., \& Akbaş, T. (2007). Physical properties of pea (Pisum sativum) seed. Journal of Food Engineering, 79(2), 731-735. http://dx.doi.org/10.1016/j.jfoodeng.2006.02.039.

Zielinska, M., \& Markowski, M. (2007). Drying behavior of carrots dried in a spout-fluidized bed dryer. Drying Technology, 25(1), 261-270. http://dx.doi.org/10.1080/07373930601161138.

Zielinska, M., Zapotoczny, P., Alves-Filho, O., Eikevik, T., \& Blaszczak, W. (2013). A multi-stage combined heat pump and microwave vacuum drying of green peas. Journal of Food Engineering, 115(3), 347-356. http://dx.doi.org/10.1016/j.jfoodeng.2012.10.047. 